\title{
Article \\ Ecotoxicological Impact of the Marine Toxin Palytoxin on the Micro-Crustacean Artemia franciscana
}

\author{
Federica Cavion ${ }^{1}\left(\mathbb{D}\right.$, Marco Pelin $\left.^{1, *} \mathbb{(}\right)$, Cristina Ponti ${ }^{1}\left(\mathbb{D}\right.$, Roberto Della Loggia ${ }^{2}$, Aurelia Tubaro ${ }^{1}$ \\ and Silvio Sosa ${ }^{1}$ (1) \\ 1 Department of Life Sciences, University of Trieste, 34127 Trieste, Italy; federica.cavion@phd.units.it (F.C.); \\ cponti@units.it (C.P.); tubaro@units.it (A.T.); ssosa@units.it (S.S.) \\ 2 Department of Chemical and Pharmaceutical Sciences, University of Trieste, 34127 Trieste, Italy; \\ rdellaloggia@units.it \\ * Correspondence: mpelin@units.it; Tel.: +39-040-5588620
}

check for updates

Citation: Cavion, F.; Pelin, M.; Ponti, C.; Della Loggia, R.; Tubaro, A.; Sosa, S. Ecotoxicological Impact of the Marine Toxin Palytoxin on the Micro-Crustacean Artemia franciscana. Mar. Drugs 2022, 20, 81. https:// doi.org/10.3390/md20020081

Academic Editor: Bill J. Baker

Received: 23 December 2021

Accepted: 15 January 2022

Published: 18 January 2022

Publisher's Note: MDPI stays neutral with regard to jurisdictional claims in published maps and institutional affiliations.

Copyright: (C) 2022 by the authors. Licensee MDPI, Basel, Switzerland. This article is an open access article distributed under the terms and conditions of the Creative Commons Attribution (CC BY) license (https:// creativecommons.org/licenses/by/ $4.0 /)$.

\begin{abstract}
Palytoxin (PLTX) is a highly toxic polyether identified in various marine organisms, such as Palythoa soft corals, Ostreopsis dinoflagellates, and Trichodesmium cyanobacteria. In addition to adverse effects in humans, negative impacts on different marine organisms have been often described during Ostreopsis blooms and the concomitant presence of PLTX and its analogues. Considering the increasing frequency of Ostreopsis blooms due to global warming, PLTX was investigated for its effects on Artemia franciscana, a crustacean commonly used as a model organism for ecotoxicological studies. At concentrations comparable to those detected in culture media of $O$. cf. ovata (1.0-10.0 nM), PLTX significantly reduced cysts hatching and induced significant mortality of the organisms, both at larval and adult stages. Adults appeared to be the most sensitive developmental stage to PLTX: significant mortality was recorded after only $12 \mathrm{~h}$ of exposure to PLTX concentrations $>1.0 \mathrm{nM}$, with a $50 \%$ lethal concentration $\left(\mathrm{LC}_{50}\right)$ of $2.3 \mathrm{nM}(95 \%$ confidence interval $=1.2-4.7 \mathrm{nM})$. The toxic effects of PLTX toward $A$. franciscana adults seem to involve oxidative stress induction. Indeed, the toxin significantly increased ROS levels and altered the activity of the major antioxidant enzymes, in particular catalase and peroxidase, and marginally glutathione-S-transferase and superoxide dismutase. On the whole, these results indicate that environmentally relevant concentrations of PLTX could have a negative effect on Artemia franciscana population, suggesting its potential ecotoxicological impact at the marine level.
\end{abstract}

Keywords: Artemia; palytoxin; ecotoxicology; mortality; oxidative stress; antioxidant enzyme activity

\section{Introduction}

The marine toxin palytoxin (PLTX; Figure 1) was firstly isolated in 1971, in Hawaii, from soft corals of the genus Palythoa [1]. The molecular target of PLTX is the sodiumpotassium pump, expressed in all animal cells; the toxin binds to the pump, transforming it into a non-selective cationic channel. This modification allows the passive flow of ions driven by their electrochemical gradient, which causes an ionic disequilibrium in both excitable and non-excitable cells [2]. In the last few decades, this toxin and a series of its analogues have also been found in other marine organisms, such as soft corals of the genus Zoanthus [3], dinoflagellates of the genus Ostreopsis [4], and marine cyanobacteria of the genus Trichodesmium [5]. In temperate areas, such as the Mediterranean Sea and along the Southern European Atlantic coasts, PLTX and its analogues have been frequently detected during Ostreopsis blooms, in particular in O. cf. ovata. In the last few decades, these blooms appear to have increased in frequency, intensity, and expansion, probably due to (i) the eutrophication of coastal areas; (ii) the increased sea surface temperature, related to the global climate changes and favouring the geographical biomass distribution of Ostreopsis cells [6,7]; and (iii) the increased levels of floating materials in the sea, including seaweeds and marine plastic, allowing the attachment of epibenthic dinoflagellates and facilitating their diffusion [8-10]. 


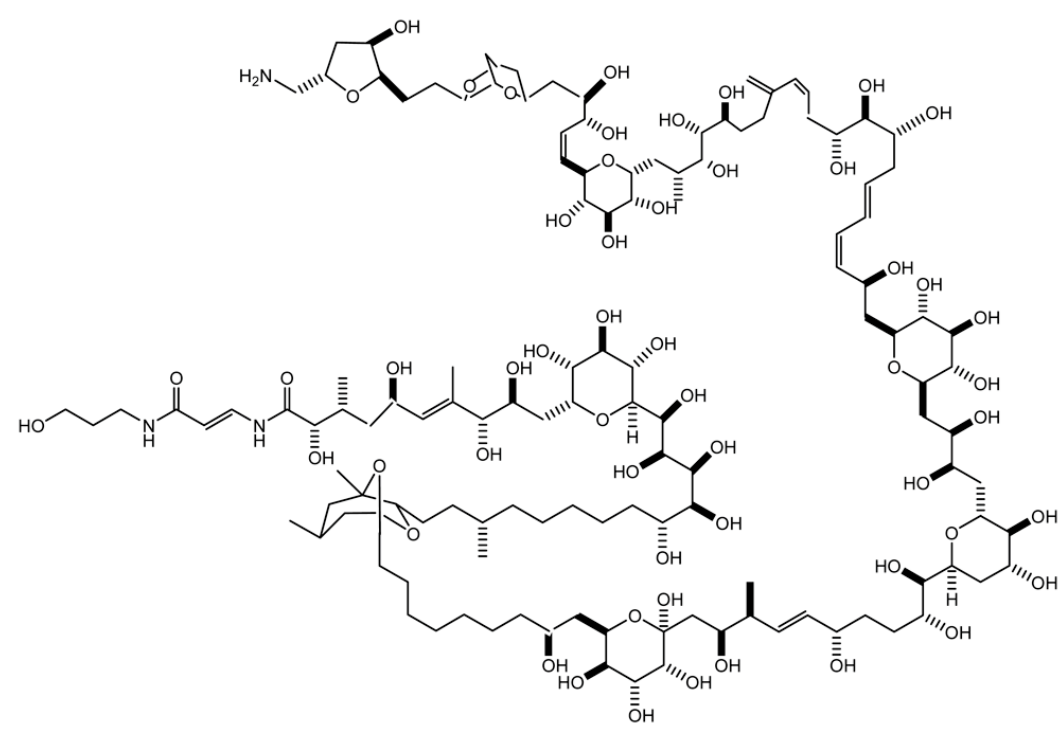

Figure 1. Structure of palytoxin.

Concomitantly to these events, a series of adverse effects in humans as well as negative impacts on different marine organisms have been documented, as summarized by several authors [11-13]. In contrast to safety issues for humans, the ecotoxicological potential of PLTX is still scarcely studied. Regarding this point, a very important aspect is the toxin impact on the marine ecosystem. In this context, cultures of PLTX-producing O. cf. ovata cells have mainly been used to investigate their effects on selected invertebrates. However, it should be underlined that some studies have been carried out without a complete qualitative and/or quantitative determination of the toxins in Ostreopsis cells or their culture media used in these studies [12,14-17]. In general, the results have showed the adverse effects of O. cf. ovata toward sea urchins, including reduced fertilization, impaired embryogenesis, and the correct development of first larval stages [14-16]. Other evidence in the bivalve Mytilus galloprovincialis, sampled during $O$. cf. ovata blooms, showed alterations of immunological and granulocyte lysosomal functions together with neurotoxic responses [13]. Furthermore, 7 and 14 days of exposure of M. galloprovincialis to cell cultures of $O$. cf. ovata in laboratory conditions revealed an impairment of the immune system, histological alterations in the digestive gland, and the increased activity of catalase, glutathione reductase, and glutathione peroxidase antioxidant enzymes [17]. In addition, Louzao et al. demonstrated a high in vitro cytotoxicity of purified PLTX toward M. galloprovincialis mantle and hepatopancreas cells: its half-maximal inhibitory concentration $\left(\mathrm{IC}_{50}\right)$ on cells' metabolic activity (alamarBlue assay) was equal to $18.23 \mathrm{nM}$ and $16.17 \mathrm{nM}$, respectively [6]. An increased mortality after exposure to $O$. cf. ovata cells has also been observed in the copepod Tigriopus fulvus and the barnacle Amphibalanus amphitrite [12]. Moreover, a hydromethanol extract of $O$. cf. ovata (estimated PLTXs content $=358.8 \mathrm{ng} / \mathrm{mL}$ ) induced lethal effects in the white shrimp Litopenaeus vannamei (moulting stage), associated with alterations of antioxidant enzymes activity, oxidative damage to lipids, the carbonylation of proteins, and the increased mRNA expression of immune genes [18].

Some Artemia species have been also used as model organisms to evaluate the ecotoxicological impact of Ostreopsis dinoflagellates and PLTX at the marine level. Using A. salina or non-identified Artemia species, the toxic effects induced by exposure to cultured O. ovata cells have been recorded by means of the increased mortality of nauplii $[12,19]$ and adults [20]. Similarly, a study showed lethal effects toward nauplii for $O$. siamensis cells [21]. Other studies on $A$. franciscana showed that exposure to O. cf. ovata cells induced a significant mortality in nauplii [22]. Lethal effects have also been recorded in $A$. franciscana nauplii exposed to O. cf. ovata cells lysates [15] and in A. salina nauplii exposed to a hydroethanol extract of Palythoa caribaeorum [23]. Other studies showed that Artemia nauplii are more sensitive to the lethal effect by the exposure to $O$. cf. ovata cells than the larvae of 
the copepods Tigriopus fulvus [12] and Sarsamphiascus cf. propinquus [22], or of the barnacle Amphibalanus amphitrite [12]. In general, these studies indicate the potential negative impact of Ostreopsis cells on Artemia organisms, ascribable to the presence of PLTXs. However, these findings were observed in Artemia species exposed to Ostreopsis sp. cells, with only a secondary extrapolation of their PLTX content, if available.

Considering the potential negative impact of Ostreopsis blooms and their toxins on the marine ecosystem, this study assessed the toxicity of PLTX toward Artemia franciscana as a marine zooplankton model organism. Apart from the lethal effect, the toxin was evaluated for its ability to induce oxidative stress through the quantitation of reactive oxygen species (ROS) and the activity of selected antioxidant enzymes (glutathione S-transferase, catalase, peroxidase, and superoxide dismutase), as well as by evaluating other parameters related to the organism motility.

\section{Results}

To assess the ecotoxicological impact of PLTX on A. franciscana, the toxin was initially evaluated for its effect on cysts hatching and mortality induction in the crustacean at two developmental stages (nauplii stage I and adults).

\subsection{Effects of PLTX on A. franciscana Cysts Hatching}

The effect of PLTX $(0.1,1.0$, and $10.0 \mathrm{nM})$ on A. franciscana cysts hatching was evaluated after $96 \mathrm{~h}$ of exposure. As compared to cysts not exposed to PLTX (negative control), the toxin induced a significant decrease of hatching $(49 \% ; p<0.01)$ only at the highest concentration (10.0 nM) (Figure 2).

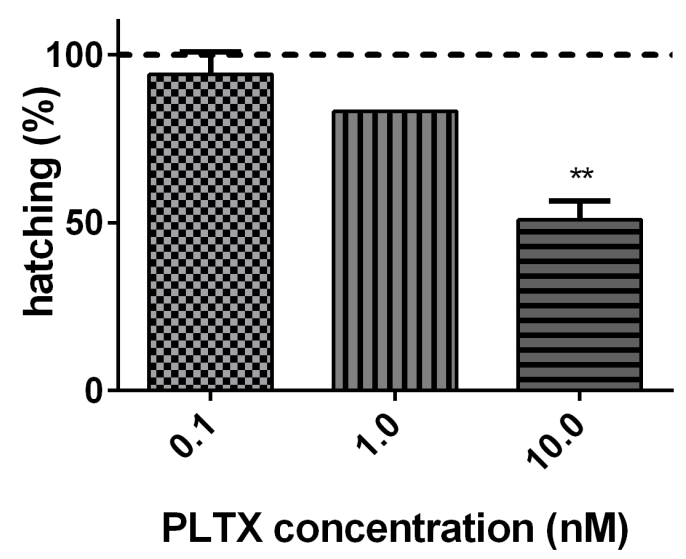

Figure 2. Percentage of $A$. franciscana cysts hatching after $96 \mathrm{~h}$ exposure to PLTX (0.1-10.0 nM) evaluated by stereomicroscope observation. Data are presented as \% of free-hatched nauplii with respect to the total number of cysts exposed to the toxin and are expressed as mean $\pm \mathrm{SE}$ of three experiments. Dashed line represents the hatching of cysts not exposed to the toxin (negative control). Statistical differences: ${ }^{* *} p<0.01$ (one-way ANOVA and Bonferroni post-test).

\subsection{Effects of PLTX on A. franciscana Mortality}

The ability of PLTX $(0.1,1.0$, and $10.0 \mathrm{nM})$ to induce mortality of $A$. franciscana nauplii stage I ( $24 \mathrm{~h}$ after hatching) and adults was evaluated after increasing times of exposure up to $72 \mathrm{~h}$. PLTX induced a significant mortality of nauplii starting from $24 \mathrm{~h}$ of exposure to the concentrations of 1.0 and $10.0 \mathrm{nM}$. The lowest concentration $(0.1 \mathrm{nM})$ induced a significant mortality only after $72 \mathrm{~h}$ of exposure $(47 \% ; p<0.05)$, when the highest toxin concentration $(10.0 \mathrm{nM})$ provoked $100 \%$ mortality of nauplii (Figure 3a). At this exposure time, the toxin concentration inducing 50\% nauplii mortality $\left(\mathrm{LC}_{50}\right)$ was $0.2 \mathrm{nM}(95 \%$ confidence interval (C.I.) $=0.1-2.7 \mathrm{nM})$.

In adults, PLTX induced a significant mortality after only $12 \mathrm{~h}$ of exposure to the concentrations of $1.0(35 \% ; p<0.001)$ and $10.0 \mathrm{nM}(64 \% ; p<0.0001)$, with an $\mathrm{LC}_{50}$ of $2.3 \mathrm{nM}$ $($ C.I. $=1.2-4.7 \mathrm{nM})$. The lowest toxin concentration $(0.1 \mathrm{nM})$ induced a significant mortality 
after only $48 \mathrm{~h}$ of exposure $(83 \% ; p<0.0001)$, whereas $100 \%$ mortality was induced by $72 \mathrm{~h}$ of exposure to all PLTX concentrations (Figure $3 b$ ).

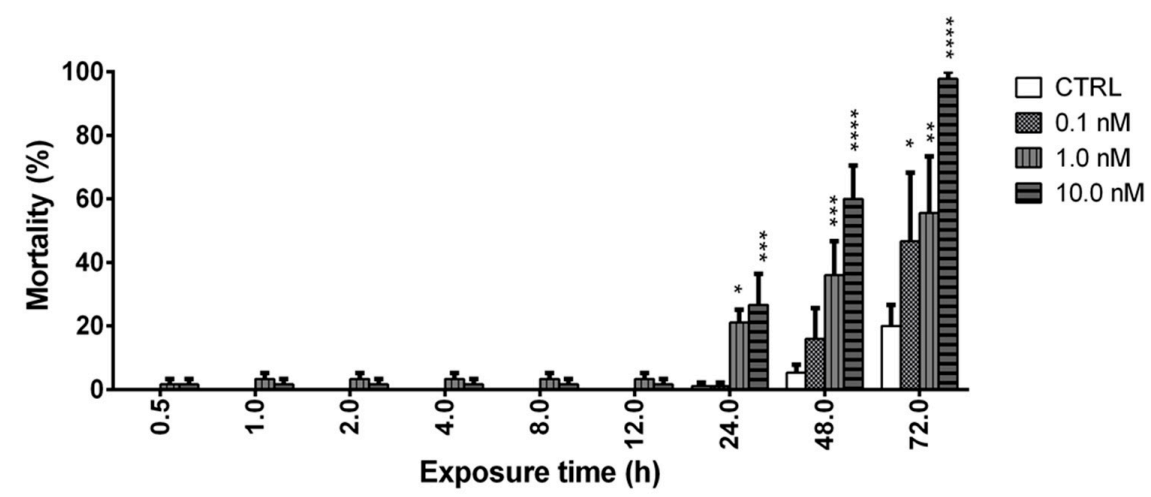

(a)

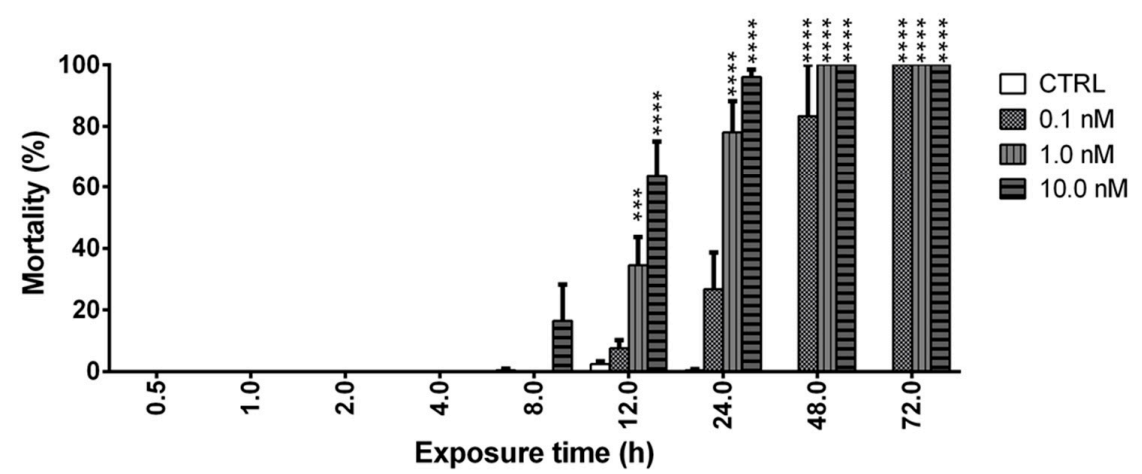

(b)

Figure 3. Mortality of Artemia nauplii (a) or adults (b) exposed to PLTX (0.1-10.0 nM) up to $72 \mathrm{~h}$, evaluated by stereomicroscope. Data are presented as \% of dead organisms with respect to the total number of animals and are expressed as mean $\pm \mathrm{SE}$ of three experiments. Statistical differences: ${ }^{*} p<0.05 ;{ }^{* *} p<0.01 ;{ }^{* * *} p<0.001 ;{ }^{* * * *} p<0.0001$ (two-way ANOVA and Bonferroni post-test).

These results suggest that $A$. franciscana adults are more sensitive than nauplii stage I to the toxic effects of PLTX, which is able to significantly increase adults' mortality after only $12 \mathrm{~h}$ of exposure. Thus, the subsequent analyses were carried out on adults exposed to PLTX for $12 \mathrm{~h}$.

\subsection{Effect of PLTX on ROS Production in A. franciscana Adults}

ROS production in A. franciscana adults exposed to PLTX for $12 \mathrm{~h}$ was evaluated by the DCFDA fluorescence assay. As compared to the negative control, the toxin induced a significant increase of ROS at the concentrations of 1.0 and $10.0 \mathrm{nM}(42 \%$ and $39 \%$, respectively; $p<0.05$ ) (Figure 4 ).

\subsection{Effect of PLTX on Antioxidant Enzymes Activity in A. franciscana Adults}

The exposure of $A$. franciscana adults to PLTX for $12 \mathrm{~h}$ slightly altered the activity of glutathione S-transferase (GST), catalase (CAT), peroxidase (POD), and superoxide dismutase (SOD) (Figure 5). The most significant effect was recorded for CAT (Figure 5b), whose activity was significantly increased by exposure to 1.0 and $10.0 \mathrm{nM}$ PLTX ( $53 \%$ and $46 \%$, respectively; $p<0.01$ ) (Figure $5 b$ ). The exposure of $A$. franciscana to PLTX also induced a slight but not significant increase of GST and SOD activities (Figure 5a,d). On the contrary, POD activity was significantly decreased $(46 \%)$ only at the highest toxin concentration $(10.0 \mathrm{nM} ; p<0.05)$ (Figure 5c). 


\section{ROS production}

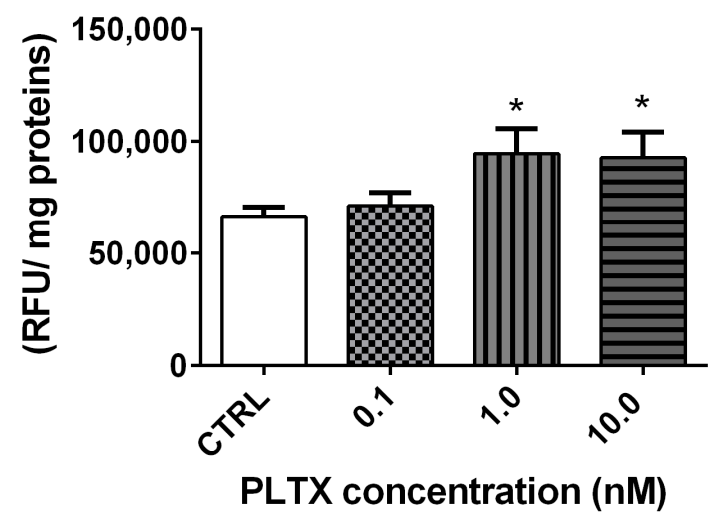

Figure 4. ROS production in A. franciscana adults after $12 \mathrm{~h}$ exposure to PLTX evaluated by the DCFDA fluorescence assay. Data are presented as relative fluorescent units normalized on milligrams of proteins in each sample and are expressed as mean \pm SE of four experiments. Statistical differences: * $p<0.05$ (Student's $t$-test).

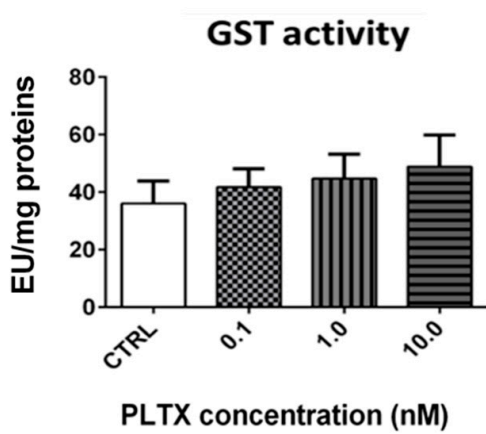

(a)

POD activity

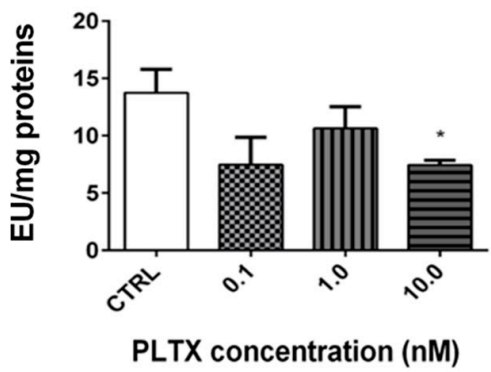

(c)

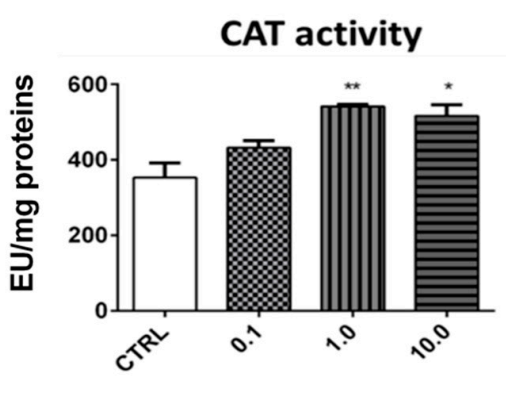

PLTX concentration (nM)

(b)

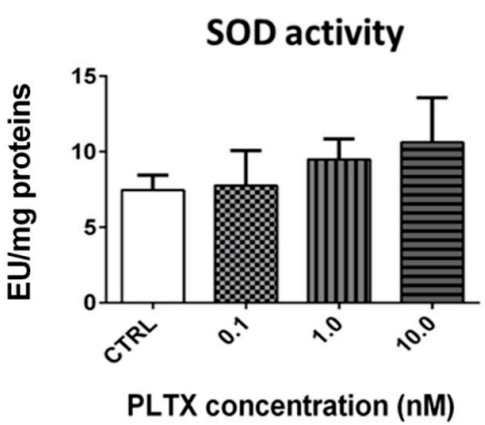

(d)

Figure 5. Activity of glutathione S-transferase (GST) (a), catalase (CAT) (b), peroxidase (POD) (c), and superoxide dismutase (SOD) (d) in A. franciscana adults after $12 \mathrm{~h}$ exposure to PLTX. Data are presented as enzymatic units $(E U)$ normalized on milligrams of proteins in each sample and are expressed as mean $\pm \mathrm{SE}$ of at least three experiments. Statistical differences: ${ }^{*} p<0.05 ;{ }^{* *} p<0.01$ (Student's $t$-test).

\subsection{Effect of PLTX on Cholinesterase Activity in A. franciscana Adults}

Stereomicroscopy observations revealed that the exposure of $A$. franciscana adults to PLTX reduced crustacean motility in a concentration-dependent manner (Video S1 in the Supplementary Materials). At the highest concentration $(10.0 \mathrm{nM})$, A. franciscana motility was almost completely hampered. To verify whether this effect could be related to an altered cholinergic transmission, the activity of cholinesterase (ChE), an enzyme involved 
in the regulation of Artemia movement [24], was evaluated in adults exposed to the toxin for $12 \mathrm{~h}$. However, the obtained results show that the enzyme activity was not significantly altered by PLTX (Figure 6).

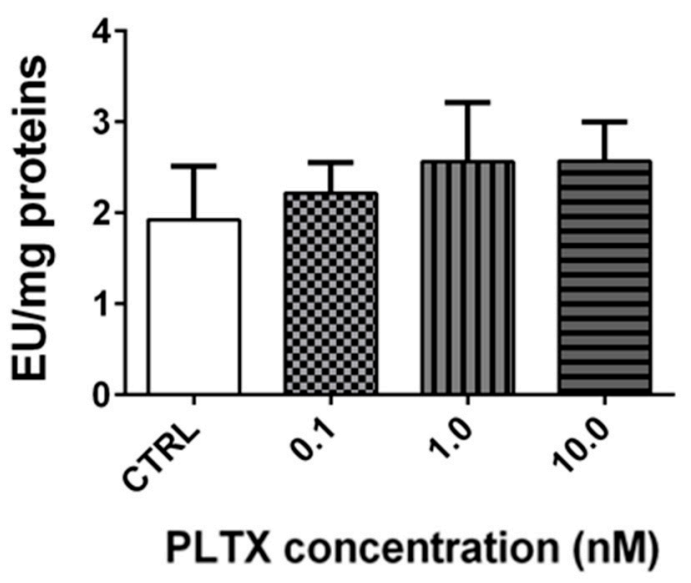

Figure 6. Cholinesterase activity in A. franciscana adults exposed to PLTX for $12 \mathrm{~h}$. Data are presented as enzymatic units $(E U)$ normalized on milligrams of proteins and expressed as mean $\pm \mathrm{SE}$ of at least three experiments.

\section{Discussion}

Artemia species are considered representative organisms of marine zooplankton and, therefore, they are widely used as organism models for ecotoxicological studies [25-28]. Indeed, Artemia species are present in natural and/or man-made hypersaline lakes, temporary desert ponds, coastal lagoons, saltern ponds, pools, and saltmarshes [29], with a wide geographic distribution, being found in 500 sites [29] spread over all the continents, except Antarctica [30]. The life cycle of species belonging to the genus Artemia includes 15 larval stages (nauplii), the juvenile stage, and the adult one. This genus includes many species with parthenogenic reproduction and six bisexual species [26]. The bisexual species have two reproductive strategies: ovoviparous reproduction, characterized by fertilized eggs developing free-swimming nauplii, or oviparous reproduction, characterized by encysted embryos production, hatching under favourable environmental conditions [29]. Artemia species are characterized by a high adaptability to environmental conditions, such as wide ranges of salinity $(5-250 \mathrm{~g} / \mathrm{L})$ and temperature $\left(6-35^{\circ} \mathrm{C}\right)$ [26]. Furthermore, these crustaceans are characterized by a short life cycle, high fecundity, small body size, wide geographic distribution, and adaptability to a variety of nutrient resources, being nonselective filter feeders. In addition, Artemia spp. are an essential food source for numerous bird species in their natural habitat [31]. For these reasons, Artemia spp. are commonly used for aquatic ecotoxicological studies, in particular for the marine environment [25] and for bioaccumulation studies of substances along the food web [32].

On the basis of these considerations, Artemia franciscana was used to assess the potential ecotoxicological impact of PLTX at the marine level. Indeed, in addition to a series of adverse effects in humans ascribed to PLTX and/or its analogues during Ostreopsis blooms, negative impacts have been observed in different invertebrate and vertebrate marine organisms $[33,34]$.

The toxin effects on $A$. franciscana were evaluated at concentrations (0.1-10.0 nM) comparable to those detected in culture media of $O$. cf. ovata cells [35]. The effects were initially evaluated on three developmental stages of $A$. franciscana: cysts (toxin effect on cysts hatching), nauplii stage I, and adults (organisms' mortality induced by the toxin). The hatching assay, which is rapid, simple, and sensitive [36], showed that the exposure of A. franciscana cysts to PLTX for $96 \mathrm{~h}$ induced a significant hatching reduction only at the highest concentration $(10.0 \mathrm{nM})$. Furthermore, the exposure of $A$. franciscana nauplii stage I and adults to the toxin up to $72 \mathrm{~h}$ induced a concentration- and time-dependent increase of mortality. In nauplii stage I, PLTX significantly increased the organisms' mortality $(<50 \%)$ 
starting from $24 \mathrm{~h}$ of exposure to the concentrations of 1.0 and $10.0 \mathrm{nM}$. This effect appears slightly lower than that recorded by Pezzolesi et al. [19] in Artemia sp. nauplii (species and nauplii stage not specified) exposed to PLTX for $24 \mathrm{~h}$ : a median lethal concentration (LC 50$)$ of $4.6 \mathrm{ng} / \mathrm{mL}$ (corresponding to around $1.7 \mathrm{nM}$ PLTX) was determined. This different potency might be related to differences between the Artemia species and nauplii stage used. In particular, the variable inter-species sensitivity is considered as one of the possible factors influencing the response of Artemia crustaceans to numerous substances [26,37]. Pavaux et al. [22] recorded about $80 \%$ mortality of $A$. franciscana metanauplii (stages II-III) after 24 h of exposure to $O$. cf. ovata cells (4 cells/mL; PLTX equivalents content: $44 \pm 17$ pg/cell by UHPLC-UV-HRMS). However, it is difficult to compare the results of our study with those obtained by Pavaux and colleagues since the type and the amount of the individual toxins in Ostreopsis culture were not specified. Furthermore, it is known that the major toxin produced by cultures of $O$. cf. ovata is ovatoxin-a, PLTX being produced only in traces [19].

PLTX significantly increased mortality of $A$. franciscana adults after only $12 \mathrm{~h}$ of exposure to the concentrations of 1.0 and $10.0 \mathrm{nM}$, with an $\mathrm{LC}_{50}$ of $2.3 \mathrm{nM}$ (C.I. $=1.2-4.7 \mathrm{nM}$ ). To the best of our knowledge, this is the first study assessing the toxic effects of purified PLTX on Artemia adults in comparison to nauplii, suggesting that adults are more sensitive to the toxin than larvae. This different sensitivity could be due to the incomplete development and functioning of the digestive tract in Artemia nauplii stage I [29], which could limit the toxin absorption. Indeed, Instar I larvae's lack of critical anatomical formations (i.e., mouth and anus) limits the ingestion and the possible bioaccumulation of compounds which could not be absorbed through the external surface of Artemia due to their not-sufficient lipophilicity or small dimensions, such as PLTX. Our finding is in agreement with previous studies showing that Artemia stage I nauplii are more resistant than adults to some xenobiotics, such as inorganic chemical reagents and elements (copper) [38,39] or nanomaterials [40,41]. Notwithstanding, PLTX effects recorded by our study on A. franciscana cysts hatching and its lethality for adults, as well as the effects on nauplii observed by previous studies, suggest that seawater concentrations of PLTX during Ostreopsis blooms could negatively impact Artemia population in marine zooplankton.

As compared to nauplii stage I, the higher sensitivity of $A$. franciscana adults to PLTX prompted us to further investigate the toxin effects on adults after $12 \mathrm{~h}$ of exposure, the shortest exposure time at which PLTX induced a significant, but not complete, mortality. The main focus was directed toward oxidative stress, a phenomenon involved in the mechanism of PLTX toxicity exerted in both marine organisms' cells $[17,18]$ and human cells [42-44]. The exposure of $A$. franciscana adults to PLTX for $12 \mathrm{~h}$ significantly increased ROS production at the concentrations of 1.0 and $10.0 \mathrm{nM}$, inducing a significant mortality after the same exposure time. Therefore, it is conceivable that oxidative stress may be involved in the induction of mortality, knowing that ROS overproduction can damage proteins, lipids, and DNA [45] and is implicated in many cell processes, including apoptosis [46].

Oxidative stress induction by PLTX in A. franciscana is also confirmed by the slight alteration of the main antioxidant enzymes activity, specifically glutathione S-transferase (GST), catalase (CAT), peroxidase (POD), and superoxide dismutase (SOD). GST belongs to the phase II detoxification enzymes, and conjugates reduced glutathione (GSH) to a wide variety of electrophilic compounds [47]; it has also been identified at significant levels in Artemia, where it can bind a wide range of substrates [48], including xenobiotics and ROS. The first line of defence toward increased ROS levels in aquatic invertebrates is represented by SOD and CAT antioxidant enzymes [49,50]. Among peroxidases, glutathione peroxidase (GPx) has also been identified in Artemia, in particular at the larval stage [51]. In general, the major effects of PLTX on A. franciscana antioxidant enzymes involved CAT and POD. The exposure of $A$. franciscana to PLTX for $12 \mathrm{~h}$ increased CAT activity at the selected concentrations (1.0 and $10.0 \mathrm{nM})$ that also significantly increased ROS levels. On the other hand, the highest PLTX concentration $(10.0 \mathrm{nM})$ significantly decreased POD activity. This effect can be explained by the complementary roles of CAT and POD (in particular GPx) in 
the detoxification of hydrogen peroxide $\left(\mathrm{H}_{2} \mathrm{O}_{2}\right)$, with different affinities for the substrate and subcellular localizations: CAT is localized in the cytosol, while POD is localized in peroxisomes. Consequently, high levels of $\mathrm{H}_{2} \mathrm{O}_{2}$ are associated with an increased affinity for CAT, while low $\mathrm{H}_{2} \mathrm{O}_{2}$ levels are associated with a higher affinity for POD [52]. Thus, CAT and POD (in particular GPx) activity patterns are expected to vary across redox cycling compounds, depending on the nature, amount, and subcellular localization of the produced ROS [53]. An increased CAT activity associated with decreased GPx activity has already been recorded in other marine organisms exposed to the ROS inducer menadione, including the crustacean Daphnia magna [53], the mussel Mytilus edulis [54], and the fish Oncorhynchus mykiss [55].

Regarding GST and SOD activity in A. franciscana adults exposed to PLTX, despite a trend showing a slight concentration-dependent increased activity, this effect was not significant. An increased GST activity has been previously recorded in other aquatic organisms exposed to toxins different from PLTX, such as shrimps (Litopenaeus vannamei) exposed to cyanobacteria extracts containing microcystins, [56] and Artemia salina adults exposed to microcystin-LR or nodularin, in which conjugation with GSH has been shown as an initial detoxification mechanism [57]. On the contrary, the slight increase of GST activity in A. franciscana exposed to PLTX suggests a low induction of the GST detoxification system. A similar conclusion is suggested for SOD, whose activity was not influenced by the toxin, even at its highest concentration. Nonetheless, the recorded effects indicate that PLTX can perturbate the main antioxidant systems in A. franciscana, corroborating its ability to induce ROS production and oxidative stress. However, the low effect on these enzymes' activity, especially on SOD and GST, suggests that these detoxification systems are not sufficiently activated to protect the crustacean from PLTX toxicity. In addition, the slight increase of these ROS-detoxification systems and the low, albeit significant, increase of ROS levels induced by the toxin suggest that oxidative stress might not be the primary and/or the only mechanism leading to Artemia death. Thus, we cannot exclude the possibility that other physiological perturbations may co-occur to induce the organism death.

Stereomicroscopy observations of $A$. franciscana exposed to PLTX showed a concentrationdependent decrease of adults' motility, as previously noted in A. salina adults exposed to O. cf. ovata cells [20]. Hypothesizing a PLTX effect on the cholinergic transmission system, the activity of cholinesterase has been evaluated in adults exposed to PLTX, considering the role of the enzyme in maintaining the normal neuromuscular function. In fact, an increased level of the neurotransmitter acetylcholine in the synapses, consequent to cholinesterase enzymes inhibition by xenobiotics, can impair the neuromuscular functions [58]. For this reason, cholinesterase activity is considered a biomarker of toxicity in Artemia spp. as well as in other marine invertebrates $[24,37]$. However, cholinesterase activity was not influenced in A. franciscana adults exposed to PLTX, suggesting that the decreased crustacean motility is not related to an impaired enzyme activity by the toxin. However, it should be noted that the regulation of Artemia species' locomotion is a complex biochemically-controlled phenomenon that cannot be attributed only to cholinesterase activity, even though it is one of the best characterized enzymes in these organisms. Therefore, we cannot exclude the possibility that other biochemical pathways could be involved in PLTX effects on the motility of $A$. franciscana. For instance, the reduced $A$. franciscana movements could be ascribed to an altered ion homeostasis involving the physiological control of fluid dynamics, as already hypothesized for $A$. salina adults exposed to PLTX analogues released by $O$. cf. ovata cells [20] and A. salina nauplii exposed to other toxins produced by the dinoflagellate Prorocentrum lima [59].

\section{Conclusions}

In the last few decades, Ostreopsis blooms recorded in temperate coastal waters have been frequently associated with adverse effects in humans and in different marine organisms, probably due to the production and release of PLTX and its analogues. Given the possible expansion of Ostreopsis spp. in terms of increasing blooms intensity and 
frequency as well as colonization of new areas due to the ongoing global warming, the impact of these dinoflagellates and their toxins needs to be assessed not only for humans but also for marine organisms. The present ecotoxicological study on Artemia franciscana showed that environmentally relevant PLTX concentrations induce detrimental effects on this micro-crustacean, being able to significantly reduce cysts hatching and to provoke the mortality of the organisms both at larval and adult stages. Adults turned out to be the most sensitive developmental stage of A. franciscana to PLTX, which induced oxidative stress. Indeed, the toxin significantly increased ROS levels and altered the activity of some of the major antioxidant enzymes, in particular catalase and peroxidase. Since Artemia species are members of the zooplankton community at the basis of the marine food web, a decrease of their population could also have a negative impact on organisms at a higher trophic level, and consequently on the marine biodiversity. However, further studies on other aquatic organisms are required for a complete understanding of the ecological impact of PLTX at the marine level.

\section{Materials and Methods}

\subsection{Artemia franciscana}

Artemia franciscana cysts were purchased from a commercial seller of aquatic products (Hobby; Garnelenhaus; Barsbüttel, Germany). The taxonomic identification of the species was previously confirmed by PCR sequencing [41]. A. franciscana was bred in seawater and prepared with $36 \mathrm{~g} / \mathrm{L}$ of specific salts for marine organisms (Optimum Sea basic salt; Wave) at $25^{\circ} \mathrm{C}$ under a $16: 8 \mathrm{~h}$ light/dark cycle, except for hatching, during which a constant artificial light source was provided. Nauplii collected after $24 \mathrm{~h}$ from hatching (stage I) and the adults (collected after 21 days of culture) were used. Nauplii were fed three times a week, starting after 3 days from hatching, with liquid food (Hobby-Liquizell; Garnelenhaus; Barsbüttel, Germany) up to 10 days, and subsequently with solid food (Hobby-Mikrozell; Garnelenhaus; Barsbüttel, Germany).

\subsection{Palytoxin and Experimental Design}

Palytoxin (PLTX), isolated from Palythoa tuberculosa (purity $>95 \%$ ), was purchased from Wako Pure Chemicals Industries, Ltd. (Osaka, Japan). The toxin, dissolved in ethanol and distilled water at a 1:1 ratio $(v / v)$, was tested at the concentrations of $0.1,1.0$, and $10.0 \mathrm{nM}$ with a final concentration of ethanol equal to $0.5 \%$. This concentration of ethanol, which did not induce any sign of toxicity, was also included in the negative control (A. franciscana not exposed to the toxin; CTRL).

The experimental design consisted of a first step aimed at evaluating the effects of PLTX on A. franciscana at three developmental stages (cysts hatching and the mortality of larvae and adults), to determine the most sensitive one. The mortality test was based on a concentration- and time-dependent approach to determine the optimal exposure condition for elucidating the mechanism of PLTX toxicity on the most sensitive developmental stage, in the second step of the study.

\subsection{Hatching Assay}

Hatching assay was performed according to Migliore et al. [60]. Briefly, in each well of a 96-well plate, 10 cysts were suspended in $200 \mu \mathrm{L}$ of seawater and exposed to PLTX (0.1, 1.0 , and $10.0 \mathrm{nM}$ ). The number of nauplii was determined every $24 \mathrm{~h}$, up to $96 \mathrm{~h}$, under a stereomicroscope at a $3 \times$ magnification (Kyowa; Tokyo, Japan). At $96 \mathrm{~h}$, hatching was calculated as the ratio between the number of free-hatched nauplii and the number of cysts and expressed as \% with respect to the negative control (CTRL).

\subsection{Mortality Assay}

The mortality of nauplii stage I and adults after exposure to PLTX (0.1-10.0 nM) was expressed as the percentage of dead organisms with respect to the total number of the animals in each sample. The mortality of nauplii stage I was evaluated on 5 nauplii/well 
suspended in $200 \mu \mathrm{L}$ of seawater, using 96-well plates, while that of adults was evaluated using 24-well plates with 10 adults/well in $1.5 \mathrm{~mL}$ of seawater. Adults were fed with solid food $24 \mathrm{~h}$ before the assay and, in the case of time-course exposure up to $72 \mathrm{~h}$, also $24 \mathrm{~h}$ after it began. On the contrary, nauplii did not receive feed. According to Zulkifli et al. [61], animals were considered dead if they did not show any movement for $10 \mathrm{~s}$ under the stereomicroscope observation (Kyowa; Tokyo, Japan) at a $3 \times$ magnification (nauplii) or $1 \times$ magnification (adults).

\subsection{Reactive Oxygen Species Quantitation}

To assess oxidative stress in A. franciscana adults after exposure to PLTX for $12 \mathrm{~h}$, reactive oxygen species (ROS) were measured as previously reported [41,62]. The samples were prepared by collecting five organisms for each group of treatment, which were washed three times with $100 \mathrm{mM}$ Tris- $\mathrm{HCl}, \mathrm{pH} 7.5$, and homogenized for $15 \mathrm{~s}$ in $1 \mathrm{~mL}$ of the same buffer, using an immersion sonicator (Ultrasonic processor UP50H; Hielscher; Teltow, Germany). After centrifugation at $12,000 \times g$ for $15 \mathrm{~min}$ at $4{ }^{\circ} \mathrm{C}$, the supernatant was collected and preserved at $-80{ }^{\circ} \mathrm{C}$. ROS production was evaluated using the $2^{\prime}, 7^{\prime}$ dichlorofluorescin diacetate (DCFDA) assay as previously reported [41,62]. Briefly, using 96-well plates, $160 \mu \mathrm{L}$ of phosphate buffered saline (PBS), $20 \mu \mathrm{L}$ of $400 \mu \mathrm{M}$ DCFDA (SigmaAldrich; Milan, Italy), and $20 \mu \mathrm{L}$ of supernatant were incubated at $37{ }^{\circ} \mathrm{C}$ for $30 \mathrm{~min}$ in the dark. The fluorescence was read at $485 \mathrm{~nm}$ excitation and $520 \mathrm{~nm}$ emission, using a microplate reader (Fluorocount; Packard; Germany), and the results were expressed as relative fluorescence units (RFU) normalized on milligrams of proteins for each sample, measured using a NanoDrop 2000 instrument (Thermo Scientific; Milan, Italy).

\subsection{Preparation of A. franciscana Samples for the Quantitation of the Enzymes' Activity}

In a 96-well plate, 50 Artemia adults were exposed to PLTX (0.1-10 nM) for $12 \mathrm{~h}$ and subsequently processed as previously described $[41,63]$ : the organisms were washed three times with phosphate buffer (composed of $50 \mathrm{mM} \mathrm{Na} \mathrm{HPO}_{4}-7 \mathrm{H}_{2} \mathrm{O}$ and $\mathrm{NaH}_{2} \mathrm{PO}_{4} \mathrm{H}_{2} \mathrm{O}$, $\mathrm{pH} 7.0)$ containing EDTA ( $5 \mathrm{mM})$, sonicated in $240 \mu \mathrm{L}$ of phosphate buffer $(50 \mathrm{mM}, \mathrm{pH} 7.0)$ for $15 \mathrm{~s}$, and centrifuged at $15,000 \times \mathrm{g}$ for $25 \mathrm{~min}$ at $4{ }^{\circ} \mathrm{C}$. After protein quantitation using the NanoDrop 2000 instrument (Thermo Scientific; Milan, Italy), the supernatants were collected and preserved at $-80^{\circ} \mathrm{C}$, until the measurement of the enzymes' activity.

\subsection{Glutathione S-Transferase Activity}

Glutathione S-transferase (GST) activity in A. franciscana adults exposed to PLTX for $12 \mathrm{~h}$ was quantified using a reaction mixture of $1.3 \mathrm{mM}$ reduced L-glutathione (Sigma-Aldrich; Milan, Italy) and 1.3 mM 1-chloro-2,4-dinitrobenzene (CDNB; Sigma-Aldrich; Milan, Italy) in a potassium phosphate buffer (composed of $100 \mathrm{mM} \mathrm{K}_{2} \mathrm{HPO}_{4}$ and $\mathrm{KH}_{2} \mathrm{PO}_{4}, \mathrm{pH} 6.5$ ) $[41,63]$. In each well of a 96-well plate, $75 \mu \mathrm{L}$ of the mixture was added to $25 \mu \mathrm{L}$ of each sample and the absorbance was read immediately at $304 \mathrm{~nm}$, and subsequently every $30 \mathrm{~s}$ for $3 \mathrm{~min}$, using a microplate reader (FLUOstar Omega, BMG Labtech; Ortenberg, Germany). The blank was prepared in the same way, replacing the probe (CDNB) with the buffer.

\subsection{Catalase Activity}

Catalase (CAT) activity in $A$. franciscana adults exposed to PLTX for $12 \mathrm{~h}$ was quantified as previously described by Zhao et al. [64] on earthworms, adapting the assay for Artemia. Briefly, $20 \mu \mathrm{L}$ of each sample was added to $980 \mu \mathrm{L}$ of $10 \mathrm{mM} \mathrm{H}_{2} \mathrm{O}_{2}$ (Sigma-Aldrich; Milan, Italy) in $50 \mathrm{mM}$ phosphate buffer, pH 7.0 (composed of $\mathrm{Na}_{2} \mathrm{HPO}_{4}$ and $\mathrm{NaH}_{2} \mathrm{PO}-4 \mathrm{H}_{2} \mathrm{O}$ ), in a quartz cuvette. The absorbance was read immediately at $240 \mathrm{~nm}$, and every $30 \mathrm{~s}$ for $3 \mathrm{~min}$, using a UV-Vis spectrophotometer (Thermo Spectronic Helios Y; Thermo Scientific; Milan, Italy).

\subsection{Peroxidase Activity}

Peroxidase (POD) activity in A. franciscana adults exposed to PLTX for $12 \mathrm{~h}$ was quantified according to the protocol reported by Zhao et al. [64]. In each well of a 96-well 
plate, $50 \mu \mathrm{L}$ of $A$. franciscana sample was added to $100 \mu \mathrm{L}$ of a reaction mixture containing phosphate buffer (100 mM pH 6.0, composed of $\mathrm{Na}_{2} \mathrm{HPO}_{4}$ and $\mathrm{NaH}_{2} \mathrm{PO}-4 \mathrm{H}_{2} \mathrm{O}$ ), $3 \% \mathrm{H}_{2} \mathrm{O}_{2}$ (Sigma-Aldrich; Milan, Italy), and $100 \mathrm{mM}$ guaiacol (Sigma-Aldrich; Milan, Italy). The absorbance was read immediately at $470 \mathrm{~nm}$, and subsequently every $30 \mathrm{~s}$ for $3 \mathrm{~min}$, using a microplate reader (FLUOstar Omega, BMG Labtech; Ortenberg, Germany).

\subsection{Superoxide Dismutase Activity}

According to Zhao et al. [64], the activity of superoxide dismutase (SOD) was quantified by measuring the enzyme ability to inhibit the photochemical reduction of nitro blue tetrazolium (NBT). The assay was performed using 96-well plates, adding to each well $25 \mu \mathrm{L}$ of sample and $75 \mu \mathrm{L}$ of a reaction mixture. The reaction mixture was composed of $50 \mathrm{mM}$ phosphate buffer, $\mathrm{pH} 7.8$ (composed of $\mathrm{Na}_{2} \mathrm{HPO}_{4}$ and $\mathrm{NaH}_{2} \mathrm{PO}-4 \mathrm{H}_{2} \mathrm{O}$ ), containing $140 \mathrm{mM}$ L-methionine (Sigma-Aldrich; Milan, Italy), $750 \mu \mathrm{M}$ NBT (Sigma-Aldrich; Milan, Italy), $20 \mu \mathrm{M}$ Riboflavin (Sigma-Aldrich; Milan, Italy), and $100 \mu \mathrm{M} \mathrm{Na}{ }_{2}$ EDTA (Sigma-Aldrich; Milan, Italy). Blank was created by replacing $25 \mu \mathrm{L}$ of each sample with the same volume of phosphate buffer. The 96-well plate was incubated at room temperature for $30 \mathrm{~min}$ under a 900-lumen lamp to allow the photochemical reaction, then the absorbance was read at $560 \mathrm{~nm}$ using a microplate reader (FLUOstar Omega; BMG Labtech; Ortenberg, Germany).

\subsection{Cholinesterase Activity}

Cholinesterase (ChE) activity was measured following the procedure reported by Jemec et al. [63]. In each well of a 96-well plate, $50 \mu \mathrm{L}$ of $A$. franciscana sample was diluted with $50 \mu \mathrm{L}$ of a reaction mixture consisting of $100 \mathrm{mM}$ potassium phosphate buffer, $\mathrm{pH}$ 7.4, containing $2 \mathrm{mM}$ acetylthiocholine iodide (Sigma-Aldrich; Milan, Italy) and $1 \mathrm{mM} 2,2-$ dinitro-5,5-dithiobenzoic acid (DTNB; Sigma-Aldrich; Milan, Italy). The reaction mixture of blank was prepared replacing DTNB with the buffer. The absorbance of the sample was measured at $405 \mathrm{~nm}$, every minute for $3 \mathrm{~min}$, with a microplate reader (FLUOstar Omega; BMG Labtech; Ortenberg, Germany).

\subsection{Enzymes' Activity Data Analysis}

The enzymes' (GST, CAT, POD, and ChE) activities in Artemia samples were expressed as enzyme units $(E U)$, calculated by the following formula:

$$
E U=\frac{\frac{\Delta \text { Absorbance }}{\min }}{\varepsilon * l} * \frac{V \text { total }}{V \text { supernatant }}
$$

where $\varepsilon$ values were $9600 \mathrm{M}^{-1} * \mathrm{~cm}^{-1}$ for GST, $43.6 \mathrm{M}^{-1} * \mathrm{~cm}^{-1}$ for CAT, $0.0266 \mathrm{M}^{-1} * \mathrm{~cm}^{-1}$ for POD, and $13,600 \mathrm{M}^{-1} * \mathrm{~cm}^{-1}$ for ChE activity assays. The enzymes' activity was normalized on the $\mathrm{mg}$ of proteins $(E U / \mathrm{mg}$ proteins) of each sample. The relevant measure units were $\mathrm{nmol} / \mathrm{min}$ for GST and ChE, $\mu \mathrm{mol} / \mathrm{min}$ for CAT, and $\mathrm{mmol} / \mathrm{min}$ for POD.

One $E U$ of SOD was defined as the amount of enzyme needed to inhibit the photochemical reduction of NBT by $50 \%$, and SOD activity was reported as $E U / \mathrm{mg}$ of proteins.

\subsection{Protein Content}

The proteins in the supernatant of each A. franciscana sample prepared to determine the enzymes' activity and ROS production were quantified using a NanoDrop 2000 (Thermo Scientific; Milan, Italy) at $280 \mathrm{~nm}$.

\subsection{Statistical Analysis}

All the results are expressed as mean \pm standard errors of the mean (SE) of at least three independent experiments. $\mathrm{LC}_{50}$ values were calculated by variable slope (four-parameter) non-linear regression at a statistical confidence interval of 95\%, using the GraphPad Prism version 6. 
Depending on the biological assays, data were analysed by a one or two-way analysis of variance (ANOVA) and Bonferroni post-test, or by the Student's $t$-test, using the GraphPad Prism software version 6. Significant differences were considered as $p<0.05$.

Supplementary Materials: The following supporting information can be downloaded at: https: / / www.mdpi.com/article/10.3390/md20020081/s1, Video S1: video showing Artemia franciscana adults' movement after $12 \mathrm{~h}$ exposure to PLTX $(0.1-10.0 \mathrm{nM})$ in comparison to the control group not exposed to the toxin. The video was acquired on an inverted optical microscope at $4 \times$ magnification.

Author Contributions: Conceptualization, M.P. and S.S.; methodology, F.C. and C.P.; validation, R.D.L.; investigation, F.C.; resources, A.T.; data curation, C.P., S.S. and M.P.; writing-original draft preparation, F.C. and M.P.; writing-review and editing, S.S., A.T., M.P. and R.D.L.; supervision, M.P. and S.S. All authors have read and agreed to the published version of the manuscript.

Funding: This research received no external funding. Authors are grateful to Beneficentia Stiftung Foundation (Lichtenstein) for the financial support for the purchase of the FLUOstar Omega instrument, necessary for the analysis carried out in this study.

Institutional Review Board Statement: Not applicable.

Informed Consent Statement: Not applicable.

Conflicts of Interest: The authors declare no conflict of interest. The funders had no role in the design of the study; in the collection, analyses, or interpretation of data; in the writing of the manuscript, or in the decision to publish the results.

\section{References}

1. Moore, R.E.; Scheuer, P.J. Palytoxin: A New Marine Toxin from a Coelenterate. Science 1971, 172, 495-498. [CrossRef]

2. Rossini, G.P.; Bigiani, A. Palytoxin Action on the $\mathrm{Na}+, \mathrm{K}+-\mathrm{ATPase}$ and the Disruption of Ion Equilibria in Biological Systems. Toxicon 2011, 57, 429-439. [CrossRef]

3. Gleibs, S.; Mebs, D.; Werding, B. Studies on the Origin and Distribution of Palytoxin in a Caribbean Coral Reef. Toxicon Off. J. Int. Soc. Toxinology 1995, 33, 1531-1537. [CrossRef]

4. Usami, M.; Satake, M.; Ishida, S.; Inoue, A.; Kan, Y.; Yasumoto, T. Palytoxin Analogs from the Dinoflagellate Ostreopsis Siamensis. J. Am. Chem. Soc. 1995, 117, 5389-5390. [CrossRef]

5. Kerbrat, A.S.; Amzil, Z.; Pawlowiez, R.; Golubic, S.; Sibat, M.; Darius, H.T.; Chinain, M.; Laurent, D. First Evidence of Palytoxin and 42-Hydroxy-Palytoxin in the Marine Cyanobacterium Trichodesmium. Mar. Drugs 2011, 9, 543-560. [CrossRef] [PubMed]

6. Louzao, M.C.; Espiña, B.; Cagide, E.; Ares, I.R.; Alfonso, A.; Vieytes, M.R.; Botana, L.M. Cytotoxic Effect of Palytoxin on Mussel. Toxicon Off. J. Int. Soc. Toxinology 2010, 56, 842-847. [CrossRef] [PubMed]

7. Granéli, E.; Vidyarathna, N.K.; Funari, E.; Cumaranatunga, P.R.T.; Scenati, R. Can Increases in Temperature Stimulate Blooms of the Toxic Benthic Dinoflagellate Ostreopsis Ovata? Harmful Algae 2011, 10, 165-172. [CrossRef]

8. Larsson, M.E.; Laczka, O.F.; Suthers, I.M.; Ajani, P.A.; Doblin, M.A. Hitchhiking in the East Australian Current: Rafting as a Dispersal Mechanism for Harmful Epibenthic Dinoflagellates. Mar. Ecol. Prog. Ser. 2018, 596, 49-60. [CrossRef]

9. Casabianca, S.; Capellacci, S.; Giacobbe, M.G.; Dell'Aversano, C.; Tartaglione, L.; Varriale, F.; Narizzano, R.; Risso, F.; Moretto, P.; Dagnino, A.; et al. Plastic-Associated Harmful Microalgal Assemblages in Marine Environment. Environ. Pollut. Barking Essex 1987 2019, 244, 617-626. [CrossRef]

10. Masó, M.; Garcés, E.; Pagès, F.; Camp, J. Drifting Plastic Debris as a Potential Vector for Dispersing Harmful Algal Bloom (HAB) Species. Sci. Mar. 2003, 67, 107-111. [CrossRef]

11. Accoroni, S.; Totti, C. The Toxic Benthic Dinoflagellates of the Genus Ostreopsis in Temperate Areas: A Review. Adv. Oceanogr. Limnol. 2016, 7, 1-15. [CrossRef]

12. Faimali, M.; Giussani, V.; Piazza, V.; Garaventa, F.; Corrà, C.; Asnaghi, V.; Privitera, D.; Gallus, L.; Cattaneo-Vietti, R.; Mangialajo, L.; et al. Toxic Effects of Harmful Benthic Dinoflagellate Ostreopsis Ovata on Invertebrate and Vertebrate Marine Organisms. Mar. Environ. Res. 2012, 76, 97-107. [CrossRef]

13. Gorbi, S.; Bocchetti, R.; Binelli, A.; Bacchiocchi, S.; Orletti, R.; Nanetti, L.; Raffaelli, F.; Vignini, A.; Accoroni, S.; Totti, C.; et al. Biological Effects of Palytoxin-like Compounds from Ostreopsis Cf. Ovata: A Multibiomarkers Approach with Mussels Mytilus Galloprovincialis. Chemosphere 2012, 89, 623-632. [CrossRef]

14. Neves, R.A.F.; Contins, M.; Nascimento, S.M. Effects of the Toxic Benthic Dinoflagellate Ostreopsis Cf. Ovata on Fertilization and Early Development of the Sea Urchin Lytechinus Variegatus. Mar. Environ. Res. 2018, 135, 11-17. [CrossRef] [PubMed]

15. Pagliara, P.; Caroppo, C. Toxicity Assessment of Amphidinium Carterae, Coolia Cfr. Monotis and Ostreopsis Cfr. Ovata (Dinophyta) Isolated from the Northern Ionian Sea (Mediterranean Sea). Toxicon 2012, 60, 1203-1214. [CrossRef] [PubMed] 
16. Privitera, D.; Giussani, V.; Isola, G.; Faimali, M.; Piazza, V.; Garaventa, F.; Asnaghi, V.; Cantamessa, E.; Cattaneo-Vietti, R.; Chiantore, M. Toxic Effects of Ostreopsis Ovata on Larvae and Juveniles of Paracentrotus Lividus. Harmful Algae 2012, 18, 16-23. [CrossRef]

17. Gorbi, S.; Avio, G.C.; Benedetti, M.; Totti, C.; Accoroni, S.; Pichierri, S.; Bacchiocchi, S.; Orletti, R.; Graziosi, T.; Regoli, F. Effects of Harmful Dinoflagellate Ostreopsis Cf. Ovata Exposure on Immunological, Histological and Oxidative Responses of Mussels Mytilus Galloprovincialis. Fish Shellfish Immunol. 2013, 35, 941-950. [CrossRef] [PubMed]

18. Cen, J.; Cui, L.; Duan, Y.; Zhang, H.; Lin, Y.; Zheng, J.; Lu, S. Effects of Palytoxins Extracted from Ostreopsis Ovata on the Oxidative Stress and Immune Responses in Pacific White Shrimp Litopenaeus Vannamei. Fish Shellfish Immunol. 2019, 95, 670-678. [CrossRef]

19. Pezzolesi, L.; Guerrini, F.; Ciminiello, P.; Dell'Aversano, C.; Iacovo, E.D.; Fattorusso, E.; Forino, M.; Tartaglione, L.; Pistocchi, R. Influence of Temperature and Salinity on Ostreopsis Cf. Ovata Growth and Evaluation of Toxin Content through HR LC-MS and Biological Assays. Water Res. 2012, 46, 82-92. [CrossRef]

20. Neves, R.A.F.; Fernandes, T.; dos Santos, L.N.; Nascimento, S.M. Toxicity of Benthic Dinoflagellates on Grazing, Behavior and Survival of the Brine Shrimp Artemia Salina. PLoS ONE 2017, 12, e0175168. [CrossRef]

21. Rhodes, L.; Adamson, J.; Suzuki, T.; Briggs, L.; Garthwaite, I. Toxic Marine Epiphytic Dinoflagellates, Ostreopsis Siamensis and Coolia Monotis (Dinophyceae), in New Zealand. N. Z. J. Mar. Freshw. Res. 2000, 34, 371-383. [CrossRef]

22. Anne-Sophie, P.; Julie, R.; Laurence, G.-G.; Sophie, M.; Eva, T.; Thomas, O.P.; Rodolphe, L.; Stéphane, G. Effects of the Toxic Dinoflagellate Ostreopsis Cf. Ovata on Survival, Feeding and Reproduction of a Phytal Harpacticoid Copepod. J. Exp. Mar. Biol. Ecol. 2019, 516, 103-113. [CrossRef]

23. Guppy, R.; Ackbarali, C.; Ibrahim, D. Toxicity of Crude Organic Extracts from the Zoanthid Palythoa Caribaeorum: A Biogeography Approach. Toxicon 2019, 167, 117-122. [CrossRef] [PubMed]

24. Varò, I.; Navarro, J.C.; Amat, F.; Guilhermino, L. Characterisation of Cholinesterases and Evaluation of the Inhibitory Potential of Chlorpyrifos and Dichlorvos to Artemia Salina and Artemia Parthenogenetica. Chemosphere 2002, 48, 563-569. [CrossRef]

25. Persoone, G.; Wells, P.G. Artemia in Aquatic Toxicology: A Review. Artemia Res. Its Appl. 1987, 1, $259-275$.

26. Nunes, B.S.; Carvalho, F.D.; Guilhermino, L.M.; Van Stappen, G. Use of the Genus Artemia in Ecotoxicity Testing. Environ. Pollut. Barking Essex 1987 2006, 144, 453-462. [CrossRef] [PubMed]

27. Mackie, J.A.; Geller, J. Experimental Parameters Affecting Quantitative PCR of Artemia Franciscana: A Model for a Marine Zooplanktonic Target in Natural Plankton Samples. Limnol. Oceanogr. Methods 2010, 8, 337-347. [CrossRef]

28. Rodd, A.L.; Creighton, M.A.; Vaslet, C.A.; Rangel-Mendez, J.R.; Hurt, R.H.; Kane, A.B. Effects of Surface-Engineered NanoparticleBased Dispersants for Marine Oil Spills on the Model Organism Artemia Franciscana. Environ. Sci. Technol. 2014, 48, 6419-6427. [CrossRef] [PubMed]

29. Abatzopoulos, T.J.; Beardmore, J.; Clegg, J.S.; Sorgeloos, P. (Eds.) Artemia: Basic and Applied Biology; Biology of Aquatic Organisms; Springer: Dordrecht, The Netherlands, 2002; ISBN 978-1-4020-0746-0.

30. Triantaphyllidis, G.; Abatzopoulos, T.; Sorgeloos, P. Review of the Biogeography of the Genus Artemia (Crustacea, Anostraca). J. Biogeogr. 1998, 25, 213-226. [CrossRef]

31. Cooper, S.D.; Winkler, D.W.; Lenz, P.H. The Effect of Grebe Predation on a Brine Shrimp Population. J. Anim. Ecol. 1984, 53, 51-64. [CrossRef]

32. Soto-Jiménez, M.F.; Arellano-Fiore, C.; Rocha-Velarde, R.; Jara-Marini, M.E.; Ruelas-Inzunza, J.; Voltolina, D.; Frías-Espericueta, M.G.; Quintero-Alvarez, J.M.; Páez-Osuna, F. Biological Responses of a Simulated Marine Food Chain to Lead Addition. Environ. Toxicol. Chem. 2011, 30, 1611-1617. [CrossRef]

33. Ingarao, C.; Pagliani, T. First Report of an Ostreopsis Ovata Bloom on Abruzzo Coast (W Adriatic) Associated with Human Respiratory Intoxication. Harmful Algae News 2014, 48, 2-3.

34. Sansoni, G.; Borghini, B.; Camici, G.; Casotti, M.; Righini, P.; Rustighi, C. Fioriture algali di Ostreopsis ovata (Gonyaulacales: Dinophyceae): Un problema emergente. Biol. Ambient. 2003, 17, 17-23.

35. Guerrini, F.; Pezzolesi, L.; Feller, A.; Riccardi, M.; Ciminiello, P.; Dell'Aversano, C.; Tartaglione, L.; Iacovo, E.D.; Fattorusso, E.; Forino, M.; et al. Comparative Growth and Toxin Profile of Cultured Ostreopsis Ovata from the Tyrrhenian and Adriatic Seas. Toxicon 2010, 55, 211-220. [CrossRef] [PubMed]

36. Rotini, A.; Manfra, L.; Canepa, S.; Tornambè, A.; Migliore, L. Can Artemia Hatching Assay Be a (Sensitive) Alternative Tool to Acute Toxicity Test? Bull. Environ. Contam. Toxicol. 2015, 95, 745-751. [CrossRef]

37. Libralato, G.; Prato, E.; Migliore, L.; Cicero, A.M.; Manfra, L. A Review of Toxicity Testing Protocols and Endpoints with Artemia spp. Ecol. Indic. 2016, 69, 35-49. [CrossRef]

38. Sorgeloos, P.; Remiche-Van Der Wielen, C.; Persoone, G. The Use of Artemia Nauplii for Toxicity Tests-A Critical Analysis. Ecotoxicol. Environ. Saf. 1978, 2, 249-255. [CrossRef]

39. Toğulga, M. The Short-Term Toxicity of Two Toxicants to Artemia Nauplii. Turk. J. Zool. 1998, 22, $259-266$.

40. Rajasree, S.R.R.; Kumar, V.G.; Abraham, L.S.; Manoharan, N. Assessment on the Toxicity of Engineered Nanoparticles on the Lifestages of Marine Aquatic Invertebrate Artemia Salina. Int. J. Nanosci. 2011, 10, 1153-1159. [CrossRef]

41. Cavion, F.; Fusco, L.; Sosa, S.; Manfrin, C.; Alonso, B.; Zurutuza, A.; Loggia, R.D.; Tubaro, A.; Prato, M.; Pelin, M. Ecotoxicological Impact of Graphene Oxide: Toxic Effects on the Model Organism Artemia Franciscana. Environ. Sci. Nano 2020, 7, $3605-3615$. [CrossRef] 
42. Pelin, M.; Zanette, C.; De Bortoli, M.; Sosa, S.; Loggia, R.D.; Tubaro, A.; Florio, C. Effects of the Marine Toxin Palytoxin on Human Skin Keratinocytes: Role of Ionic Imbalance. Toxicology 2011, 282, 30-38. [CrossRef] [PubMed]

43. Pelin, M.; Ponti, C.; Sosa, S.; Gibellini, D.; Florio, C.; Tubaro, A. Oxidative Stress Induced by Palytoxin in Human Keratinocytes Is Mediated by a H+-Dependent Mitochondrial Pathway. Toxicol. Appl. Pharmacol. 2013, 266, 1-8. [CrossRef]

44. Pelin, M.; Sosa, S.; Pacor, S.; Tubaro, A.; Florio, C. The Marine Toxin Palytoxin Induces Necrotic Death in HaCaT Cells through a Rapid Mitochondrial Damage. Toxicol. Lett. 2014, 229, 440-450. [CrossRef] [PubMed]

45. Schieber, M.; Chandel, N.S. ROS Function in Redox Signaling and Oxidative Stress. Curr. Biol. 2014, 24, R453-R462. [CrossRef] [PubMed]

46. Ott, M.; Gogvadze, V.; Orrenius, S.; Zhivotovsky, B. Mitochondria, Oxidative Stress and Cell Death. Apoptosis Int. J. Program. Cell Death 2007, 12, 913-922. [CrossRef] [PubMed]

47. Boyland, E.; Chasseaud, L.F. The Role of Glutathione and Glutathione S-Transferases in Mercapturic Acid Biosynthesis. In Advances in Enzymology — and Related Areas of Molecular Biology; Nord, F.F., Ed.; John Wiley \& Sons, Inc.: Hoboken, NJ, USA, 2006; pp. 173-219; ISBN 978-0-470-12277-8.

48. Papadopoulos, A.I.; Lazaridou, E.; Mauridou, G.; Touraki, M. Glutathione S-Transferase in the Branchiopod Artemia Salina. Mar. Biol. 2004, 144, 295-301. [CrossRef]

49. Livingstone, D.R. Organic Xenobiotic Metabolism in Marine Invertebrates. In Advances in Comparative and Environmental Physiology: Volume 7; Houlihan, D.F., Livingstone, D.R., Lee, R.F., Eds.; Springer: Berlin, Heidelberg, 1991; pp. 45-185. ISBN 978-3-642-75897-3.

50. Barata, C.; Navarro, J.C.; Varo, I.; Riva, M.C.; Arun, S.; Porte, C. Changes in Antioxidant Enzyme Activities, Fatty Acid Composition and Lipid Peroxidation in Daphnia Magna during the Aging Process. Comp. Biochem. Physiol. B Biochem. Mol. Biol. 2005, 140, 81-90. [CrossRef]

51. Nunes, B.; Carvalho, F.; Guilhermino, L. Effects of Widely Used Pharmaceuticals and a Detergent on Oxidative Stress Biomarkers of the Crustacean Artemia Parthenogenetica. Chemosphere 2006, 62, 581-594. [CrossRef]

52. Viciano, E.; Monroig, Ó.; Barata, C.; Peña, C.; Navarro, J.C. Antioxidant Activity and Lipid Peroxidation in Artemia Nauplii Enriched with DHA-Rich Oil Emulsion and the Effect of Adding an External Antioxidant Based on Hydroxytyrosol. Aquac. Res. 2017, 48, 1006-1019. [CrossRef]

53. Barata, C.; Varo, I.; Navarro, J.C.; Arun, S.; Porte, C. Antioxidant Enzyme Activities and Lipid Peroxidation in the Freshwater Cladoceran Daphnia Magna Exposed to Redox Cycling Compounds. Comp. Biochem. Physiol. Part C Toxicol. Pharmacol. 2005, 140, 175-186. [CrossRef] [PubMed]

54. Livingstone, D.R.; Martinez, P.G.; Michel, X.; Narbonne, J.F.; O’Hara, S.; Ribera, D.; Winston, G.W. Oxyradical Production as a Pollution-Mediated Mechanism of Toxicity in the Common Mussel, Mytilus Edulis L., and Other Molluscs. Funct. Ecol. 1990, 4, 415-424. [CrossRef]

55. Stephensen, E.; Sturve, J.; Förlin, L. Effects of Redox Cycling Compounds on Glutathione Content and Activity of GlutathioneRelated Enzymes in Rainbow Trout Liver. Comp. Biochem. Physiol. Part C Toxicol. Pharmacol. 2002, 133, 435-442. [CrossRef]

56. Gonçalves-Soares, D.; Zanette, J.; Yunes, J.S.; Yepiz-Plascencia, G.M.; Bainy, A.C.D. Expression and Activity of Glutathione S-Transferases and Catalase in the Shrimp Litopenaeus Vannamei Inoculated with a Toxic Microcystis Aeruginosa Strain. Mar. Environ. Res. 2012, 75, 54-61. [CrossRef]

57. Beattie, K.A.; Ressler, J.; Wiegand, C.; Krause, E.; Codd, G.A.; Steinberg, C.E.W.; Pflugmacher, S. Comparative Effects and Metabolism of Two Microcystins and Nodularin in the Brine Shrimp Artemia Salina. Aquat. Toxicol. Amst. Neth. 2003, 62, 219-226. [CrossRef]

58. Olsen, T.; Ellerbeck, L.; Fisher, T.; Callaghan, A.; Crane, M. Variability in Acetylcholinesterase and Glutathione S-Transferase Activities in Chironomus Riparius Meigen Deployed in Situ at Uncontaminated Field Sites. Environ. Toxicol. Chem. 2001, 20, 1725-1732. [CrossRef] [PubMed]

59. Ajuzie, C.C. Palatability and Fatality of the Dinoflagellate Prorocentrum Lima to Artemia Salina. J. Appl. Phycol. 2007, 19, 513-519. [CrossRef]

60. Migliore, L.; Civitareale, C.; Brambilla, G.; Delupis, G.D.D. Toxicity of Several Important Agricultural Antibiotics to Artemia. Water Res. 1997, 31, 1801-1806. [CrossRef]

61. Zulkifli, S.Z.; Aziz, F.Z.A.; Ajis, S.Z.M.; Ismail, A. Nauplii of Brine Shrimp (Artemia Salina) as a Potential Toxicity Testing Organism for Heavy Metals Contamination. In Proceedings of the From Sources to Solution; Aris, A.Z., Tengku Ismail, T.H., Harun, R., Abdullah, A.M., Ishak, M.Y., Eds.; Springer: Singapore, 2014; pp. 233-237.

62. Zhu, S.; Luo, F.; Chen, W.; Zhu, B.; Wang, G. Toxicity Evaluation of Graphene Oxide on Cysts and Three Larval Stages of Artemia Salina. Sci. Total Environ. 2017, 595, 101-109. [CrossRef] [PubMed]

63. Jemec, A.; Tisler, T.; Drobne, D.; Sepcić, K.; Jamnik, P.; Ros, M. Biochemical Biomarkers in Chronically Metal-Stressed Daphnids Comp. Biochem. Physiol. Toxicol. Pharmacol. CBP 2008, 147, 61-68. [CrossRef]

64. Zhao, S.; Wang, Y.; Duo, L. Biochemical Toxicity, Lysosomal Membrane Stability and DNA Damage Induced by Graphene Oxide in Earthworms. Environ. Pollut. Barking Essex 1987 2021, 269, 116225. [CrossRef] [PubMed] 